\title{
Risk of Hepatitis B Virus Reactivation in HBsAg-negative, Anti-HBc- negative Patients Receiving Rituximab for Autoimmune Diseases in Hepatitis B Virus Endemic Areas
}

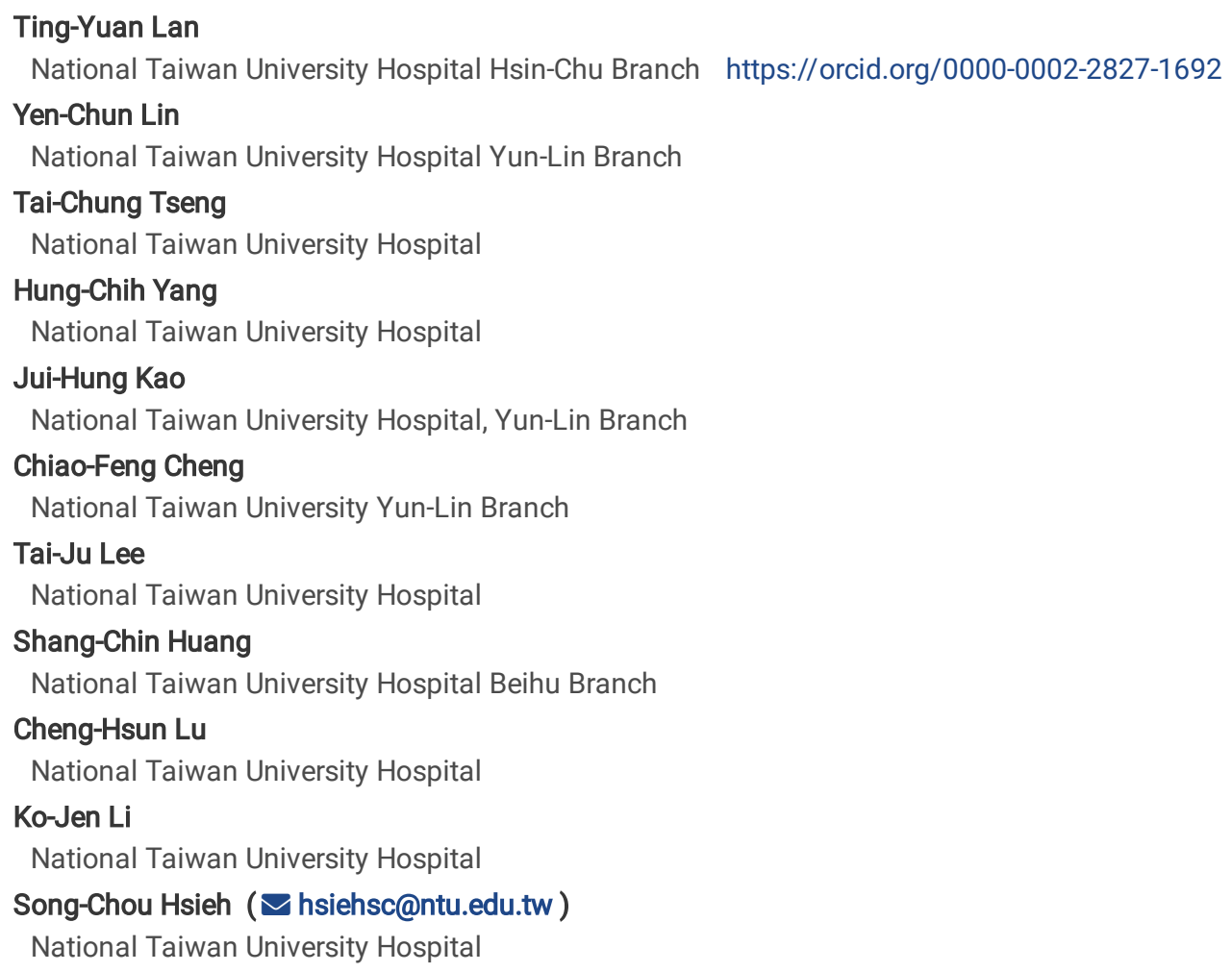

\section{Research Article}

Keywords: Hepatitis B virus reactivation, hepatitis B associated hepatitis flare, autoimmune diseases, rheumatoid arthritis, rituximab, anti-CD20 therapy, HBsAg-negative, occult hepatitis B infection, seronegative occult hepatitis B infection, hepatitis B virus screening

Posted Date: September 27th, 2021

DOI: https://doi.org/10.21203/rs.3.rs-927997/v1

License: (c) (i) This work is licensed under a Creative Commons Attribution 4.0 International License. Read Full License 


\section{Abstract \\ Background}

Rituximab is known to be associated with a high resolved hepatitis B virus (HBV) reactivation rate in patients with resolved $\mathrm{HBV}$ infection and hematologic malignancy. However, data regarding HBV reactivation in rheumatic patients receiving rituximab is limited.

\section{Aims}

To assess the HBV reactivation in HBsAg-negative patients receiving rituximab for autoimmune diseases in a large real-world cohort.

\section{Methods}

From March 2006 to December 2019, 900 patients with negative HBsAg receiving at least one cycle of rituximab for autoimmune diseases in a tertiary medical center in Taiwan were retrospectively reviewed. Clinical outcomes and factors associated with HBV reactivation were analyzed.

\section{Results}

After a median follow-up period of 3.3 years, 21 patients developed HBV reactivation, among which 17 patients were positive for anti-HBc and 4 were negative. Thirteen patients had clinical hepatitis flare, while 8 patients had HBsAg seroreversion without hepatitis. Old age, anti-HBc positivity, and undetectable serum anti-HBs level at rituximab initiation were associated with HBV reactivation. There was no significant difference in the HBV reactivation risk between rheumatoid arthritis and other autoimmune diseases. Among anti-HBc-negative patients, subjects without HBV vaccination at birth had an increased risk of HBV reactivation $(4 / 368,1.1 \%)$ compared with those who received vaccination $(0 / 126,0 \%)$.

\section{Conclusions}

In HBV endemic areas, patients with negative anti-HBc, especially those without vaccination at birth, were still at risk for HBV reactivation after receiving rituximab. Regular monitoring of HBV serology should be considered for all HBsAg-negative patients receiving rituximab for autoimmune diseases.

\section{Introduction}

Hepatitis B virus (HBV) infection is a major health issue in endemic areas such as Asian countries, and HBV reactivation (HBVr) is a life-threatening complication. ${ }^{1}$ The risk of reactivation not only exists for patients with positive hepatitis B surface antigen (HBsAg); patients with resolved HBV were also reported to have HBVr after chemotherapy or immunosuppressants, especially rituximab. A pooled analysis of studies revealed a $16.9 \%$ reactivation rate in patients with resolved $\mathrm{HBV}$ receiving rituximab-containing chemotherapy. ${ }^{2}$

Rituximab is one of the most important immunomodulators in rheumatic diseases for its ability to deplete autoreactive B cells and subsequently decrease autoantibody production. It has been approved to be used in rheumatoid arthritis (RA) and anti-neutrophil cytoplasmic antibody (ANCA)associated vasculitis by FDA and European regulatory agency. It is also widely used and investigated in severe autoimmune diseases, for example, systemic lupus erythematosus, inflammatory myositis, Sjogren's syndrome, systemic sclerosis, and antiphospholipid syndrome. ${ }^{3-6}$ Patients with autoimmune diseases may require long-term rituximab administration to maintain remission and prevent relapses, although the optimal dosing timing and interval remain controversial due to the complex nature of autoimmune diseases. ${ }^{7,8}$ For HBsAg-positive rheumatic patients receiving rituximab, the risk was as high as $30-60 \%$, necessitating antiviral prophylaxis. 9,10 However, for patients with resolved HBV, evidence was available only in RA patients and the reported reactivation rates were inconsistent, ranging from 0 to $10 \% .{ }^{11-16}$ In patients receiving rituximab for other autoimmune diseases, the risk of HBVr remains unclear.

Therefore, this study aims to assess clinical outcomes and risk factors for HBVr in HBsAg-negative patients receiving rituximab for various autoimmune diseases in a large real-world cohort.

\section{Material And Methods Study population}

From March 2006 to December 2019, HBsAg-negative patients receiving at least one cycle of rituximab for autoimmune diseases at National Taiwan University Hospital were retrospectively analyzed (Fig. 1). All patients underwent hepatic function surveillance every 1-3 months from 
rituximab initiation, and HBsAg and anti-HBs were measured when clinically indicated.

The details of rheumatic diagnosis, age, comorbidity, liver biochemical parameters (including serum aspartate aminotransferase [AST], alanine aminotransferase [ALT], total bilirubin [T-bil]), viral hepatitis B markers (HBsAg, anti-HBs, anti-HBc), and immunoglobulin G were recorded. The autoimmune diseases of individual patients were defined based on the updated classification criteria. The study was approved by the Ethics Committee of National Taiwan University Hospital (reference number 202010014RINB) in harmony with the Declaration of Helsinki.

The universal HBV vaccination program for all newborns started in Taiwan in 1986. ${ }^{17}$ All individuals who born after 1986 had received a 3-dose course of HBV vaccination at birth. Stratified by their birth date, patients born before 1986 were classified as "unvaccinated cohort", while patients born after 1986 were classified as "vaccinated cohort" for analysis.

\section{Rituximab treatment}

All patients received the first cycle of rituximab, with $375 \mathrm{mg} / \mathrm{m}^{2}$ body surface area (BSA) weekly for four consecutive weeks for ANCA vasculitis, or 500-1000 mg rituximab twice within 14 days for other autoimmune diseases. Further cycles for treatment consisting of the same regimen were repeated with a 6-12-month interval for maintenance as clinically indicated.

\section{Definition of HBV reactivation and HBV hepatitis flare}

An HBV reactivation was defined as detectable HBV DNA or reappearance of HBsAg in the serum (HBsAg seroreversion). An HBV hepatitis flare was defined as an ALT increase for more than 3 times of baseline level and $>100 \mathrm{U} / \mathrm{L}$, with concurrent HBV reacviation. ${ }^{10}$

\section{Viral hepatitis B markers testing}

The cut-off value for hepatitis B surface antigen (HBsAg) positivity was $0.05 \mathrm{IU} / \mathrm{mL}$ or $1.0 \mathrm{~S} / \mathrm{CO}$ (signal-to-cutoff ratio). The cut-off value for positive hepatitis B surface antibody (anti-HBs) and hepatitis B core antibody (anti-HBc) $10 \mathrm{mIU} / \mathrm{mL}$ and $1.0 \mathrm{~S} / \mathrm{CO}$ respectively. HBV viral load quantification was based on Roche Cobas TaqMan HBV DNA assay (detection limit at $20 \mathrm{IU} / \mathrm{mL}$ ).

\section{Statistical analysis}

The results are presented as mean with standard deviation (SD) or median with interquartile range (IQR) for continuous variables. The chi-squared test or Fisher's exact test for categorical variables was used for between-group comparisons. For continuous variables, the Mann-Whitney U test or Student's t-test was used. The cumulative incidence stratified by different variables was calculated by Kaplan-Meier analysis and the significance was determined by log-rank test. A p-value less than 0.05 was considered statistically significant. All data were analyzed by $\mathrm{R}$ version 4.0 .3 ( $\mathrm{R}$ Foundation for Statistical Computing, Vienna, Austria).

\section{Results}

\section{Study population}

Nine hundred patients with a negative HBsAg were enrolled. 406 patients had positive anti-HBc and 494 patients had negative anti-HBc. The mean age at rituximab initiation was 46.7 years, and $81 \%$ were female. The diagnoses of autoimmune diseases included rheumatoid arthritis ( $\mathrm{n}=129$ ) and other autoimmune inflammatory rheumatic diseases (AIIRDs) $(n=771)$. The patient demographics, baseline hepatitis status, liver functions, diagnoses, and concurrent disease-modifying antirheumatic drug exposures upon enrollment were summarized in Table 1. 
Table 1

Demographics, baseline characteristics and medication in HBsAg-negative patients with and without HBV reactivation

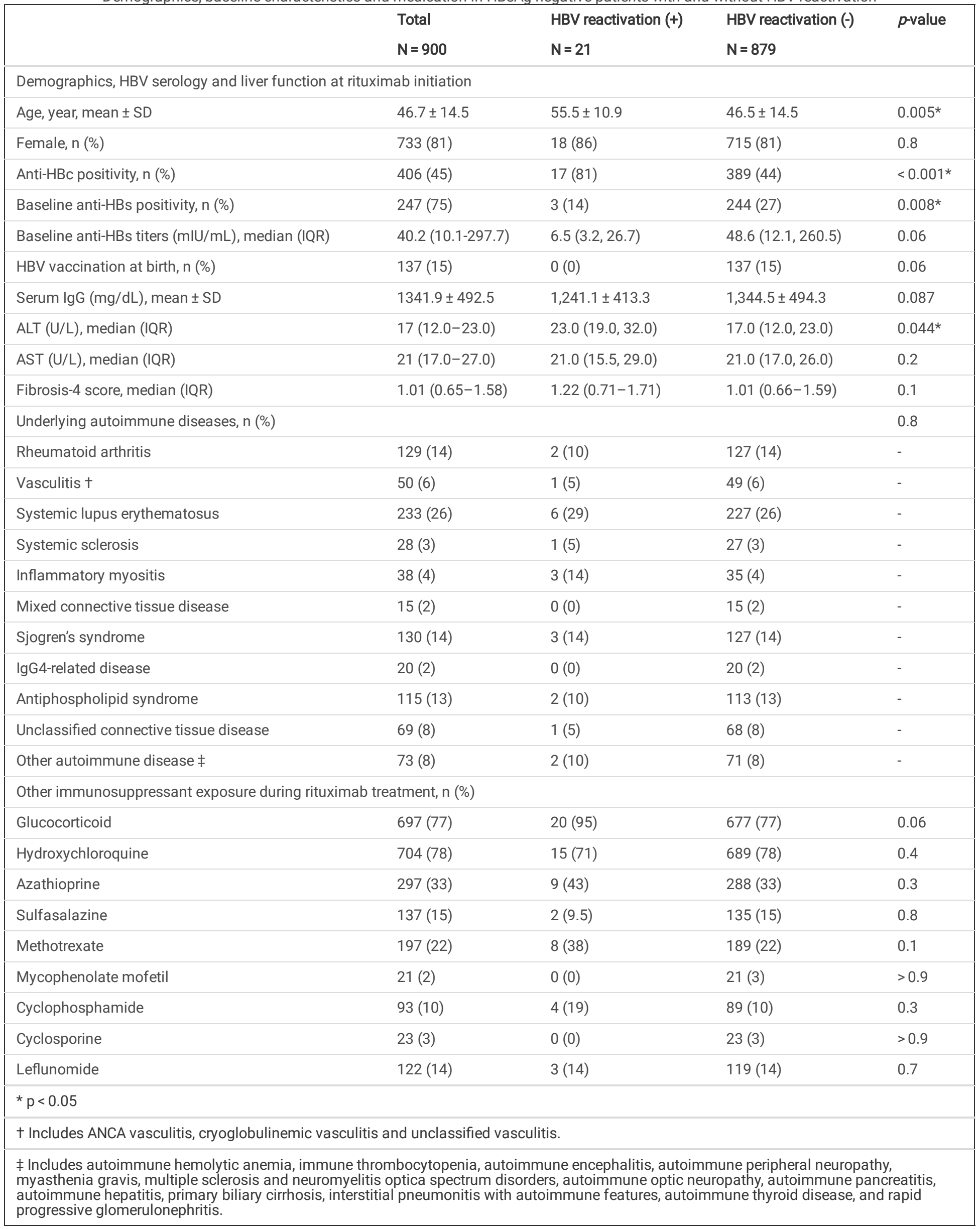




\section{Incidence of HBV reactivation}

After a median follow-up period of 3.3 years (range: $0.5-13.9)$ and median cycles of rituximab of 5 (range: 1-32), 21 patients developed HBVr. Among them, 17 patients were positive for anti-HBc and 4 were negative. 13 patients encountered clinical hepatitis flare, while 8 patients had HBsAg seroreversion without hepatitis (Fig. 1). The incidence of HBV hepatitis flare was 3.4 per 1000 person-years (total follow-up 3797 personyears).

\section{Factors associated with HBV reactivation in HBsAg-negative patients.}

Patients with HBVr had an older age (55.5 versus 46.5 years, $p=0.005)$, a higher proportion of anti-HBc positivity ( $81 \%$ versus $44 \%, p<0.001)$, and a lower proportion of anti-HBs positivity ( $14 \%$ versus $27 \%, p=0.008)$ at rituximab initiation. There were no significant differences in baseline IgG level, concomitant use of glucocorticoids or other immunosuppressants during rituximab therapy (Table 1).

The multivariate Cox regression analysis demonstrated that old age (adjusted HR 1.05, $p=0.01$ ) and presence of anti-HBc antibody (adjusted HR $11.7, p=0.03$ ) were associated with higher risk of $\mathrm{HBV}$, while anti-HBs positivity was associated with lower risk (adjusted HR $0.10, p=0.002$ ) (Table 2).

Table 2

Univariate and multivariate Cox regression analysis for risk factors of HBV reactivation in HBsAg-negative patients receiving rituximab for autoimmune diseases

\begin{tabular}{|lllll|}
\hline & Univariate & & Multivariate & \\
\cline { 2 - 5 } & HR $(95 \% \mathrm{Cl})$ & $\boldsymbol{p}$ value & HR $(95 \% \mathrm{Cl})$ & $\boldsymbol{p}$ value \\
\hline Age & $1.06(1.03-1.10)$ & $<0.001^{*}$ & $1.05(1.01-1.09)$ & $0.01^{\star}$ \\
\hline Anti-HBc positivity & $5.54(1.86-16.5)$ & $0.002^{*}$ & $11.7(1.22-112)$ & $0.03^{\star}$ \\
\hline Baseline anti-HBs positivity & $0.17(0.04-0.68)$ & $0.012^{*}$ & $0.10(0.02-0.43)$ & $0.002^{\star}$ \\
\hline Baseline serum IgG level & $1.00(1.00-1.00)$ & 0.3 & - & - \\
\hline Other autoimmune diseases versus RA & $2.16(0.50-9.31)$ & 0.3 & & \\
\hline Concomitant glucocorticoid use during rituximab & $5.18(0.69-38.7)$ & 0.11 & $5.95(0.80-44.4)$ & 0.082 \\
\hline RA = rheumatoid arthritis & & & & \\
\hline
\end{tabular}

Compared to RA patients, the diagnosis of other AlIRDs was not associated with a higher risk of HBVr (Fig. 2A, $p=0.29)$. Additionally, major AllRDs (with over 50 patients per disease in the study, including systemic lupus erythematosus, Sjogren's syndrome, antiphospholipid syndrome, vasculitis, and unclassified connective tissue disease) were not associated with higher HBVr risks when compared with RA (Fig. 2B and Supplement Table 1).

In patients with positive anti-HBc, a positive anti-HBs antibody was associated with a lower risk of $\mathrm{HBVr}$ (HR 0.13, Cl: 0.03-0.56). No significant associations were observed regarding age, baseline lgG level, different autoimmune diseases, and concomitant steroid use in the Cox proportional hazard model (Supplement Table 2).

\section{Clinical outcome of patients with HBV reactivation}

Table 3 summarized the patient characteristics in 21 individuals of HBVr. The time to HBVr from the first rituximab ranged from 7 to 144 months (median 58.5 months), and the median number of accumulated rituximab cycles was 5 (Table 3A). 
Table 3

A: Demographics, baseline characteristics and rituximab exposure of 21 patients with HBV reactivation

\begin{tabular}{|c|c|c|c|c|c|c|c|c|c|c|c|}
\hline \multirow[t]{2}{*}{ No } & \multirow{2}{*}{$\begin{array}{l}\text { Aget } \\
\text { Sex }\end{array}$} & \multirow[t]{2}{*}{ Diagnosis } & \multirow{2}{*}{$\begin{array}{l}\text { Disease } \\
\text { duration } \\
\text { (year) }\end{array}$} & \multirow{2}{*}{$\begin{array}{l}\text { Baseline } \\
\text { lgG } \\
(\mathrm{mg} / \mathrm{dL})\end{array}$} & \multirow{2}{*}{$\begin{array}{l}\text { Baseline } \\
\text { ALT } \\
\text { (U/L) }\end{array}$} & \multirow{2}{*}{$\begin{array}{l}\text { Anti- } \\
\text { HBc }\end{array}$} & \multirow{2}{*}{$\begin{array}{l}\text { Steroid } \\
\text { daily } \\
\text { dose } \\
(\mathrm{mg}) \neq\end{array}$} & \multirow{2}{*}{$\begin{array}{l}\text { Concomitant } \\
\text { immunosuppressant }\end{array}$} & \multirow{2}{*}{$\begin{array}{l}\text { Time from } \\
\text { first RTX to } \\
\text { HBV } \\
\text { reactivation } \\
\text { (months) }\end{array}$} & \multicolumn{2}{|l|}{ RTX } \\
\hline & & & & & & & & & & Cycle & $\begin{array}{l}\text { Accumulated } \\
\text { doses }(\mathrm{mg})\end{array}$ \\
\hline 1 & $\begin{array}{l}57 / \\
F\end{array}$ & AON & 2.2 & 823 & 27 & $(-)$ & 10 & $\mathrm{HCQ}, \mathrm{CYC}$ & 23 & 5 & 5000 \\
\hline 2 & $\begin{array}{l}46 / \\
F\end{array}$ & IIM & 5.4 & 1030 & 22 & $(-)$ & 2.5 & $\mathrm{HCQ}$ & 60 & 9 & 9000 \\
\hline 3 & $\begin{array}{l}69 / \\
F\end{array}$ & PSS & 8.0 & 1040 & 19 & $(-)$ & 10 & CYC, AZA, HCQ & 66 & 11 & 11000 \\
\hline 4 & $\begin{array}{l}59 / \\
F\end{array}$ & IIM & 9.1 & 972 & 53 & $(-)$ & 2.5 & MTX & 87 & 8 & 8000 \\
\hline 5 & $\begin{array}{l}35 / \\
M\end{array}$ & APS & 1.6 & 1570 & 44 & $(+)$ & 26 & $\mathrm{CYC}, \mathrm{HCQ}$ & 8 & 2 & 2000 \\
\hline 6 & $\begin{array}{l}37 / \\
F\end{array}$ & SLE & 9.2 & 1590 & 11 & $(+)$ & 10 & $\mathrm{HCQ}$ & 76 & 5 & 5000 \\
\hline 7 & $\begin{array}{l}52 / \\
F\end{array}$ & SLE & 9.1 & 1120 & 11 & $(+)$ & 2.5 & HCQ & 57 & 8 & 8000 \\
\hline 8 & $\begin{array}{l}71 / \\
F\end{array}$ & SLE & 1.3 & 1110 & 20 & $(+)$ & 15 & $\mathrm{HCQ}$ & 12 & 3 & 3000 \\
\hline 9 & $\begin{array}{l}56 / \\
F\end{array}$ & SLE & 8.9 & 1220 & 18 & $(+)$ & 10 & $\mathrm{HCQ}$ & 7 & 1 & 1000 \\
\hline 10 & $\begin{array}{l}65 / \\
F\end{array}$ & RA & 3.3 & 1300 & 28 & $(+)$ & 2.5 & MTX, SSZ & 25 & 3 & 3000 \\
\hline 11 & $\begin{array}{l}58 / \\
F\end{array}$ & IIM & 0.8 & 846 & 58 & $(+)$ & 15 & MTX, HCQ & 7 & 1 & 1000 \\
\hline 12 & $\begin{array}{l}52 / \\
F\end{array}$ & PSS & 6.8 & 844 & 11 & $(+)$ & 2.5 & HCQ, colchicine & 80 & 3 & 3000 \\
\hline 13 & $\begin{array}{l}49 / \\
F\end{array}$ & SLE & 8.7 & 1350 & 16 & $(+)$ & 0 & HCQ, colchicine & 64 & 10 & 10000 \\
\hline 14 & $\begin{array}{l}62 / \\
F\end{array}$ & UCTD & 14.2 & $\mathrm{n} / \mathrm{a}$ & 42 & $(+)$ & 10 & ADA, LEF, HCQ & 144 & 19 & 19000 \\
\hline 15 & $\begin{array}{l}66 / \\
F\end{array}$ & SLE & 22.7 & 1760 & 14 & $(+)$ & 5 & AZA, LEF & 70 & 6 & 6000 \\
\hline 16 & $\begin{array}{l}55 / \\
F\end{array}$ & APS & 6 & 997 & 15 & $(+)$ & 5 & $\mathrm{HCQ}$ & 67 & 9 & 9000 \\
\hline 17 & $\begin{array}{l}65 / \\
F\end{array}$ & $A E$ & 6.2 & 1110 & 36 & $(+)$ & 2.5 & $\mathrm{HCQ}, \mathrm{CYC}$ & 62 & 8 & 8500 \\
\hline 18 & $\begin{array}{l}68 / \\
F\end{array}$ & PSS & 11.4 & 1300 & 21 & $(+)$ & 2.5 & LEF, HCQ & 62 & 10 & 10000 \\
\hline 19 & $\begin{array}{l}68 / \\
M\end{array}$ & SSc & 7.8 & 2710 & 57 & $(+)$ & 10 & MTX, HCQ & 48 & 3 & 3000 \\
\hline 20 & $\begin{array}{l}75 / \\
M\end{array}$ & AAV & 3.4 & 1140 & 30 & $(+)$ & 5 & HCQ & 35 & 6 & 6000 \\
\hline 21 & $\begin{array}{l}68 / \\
F\end{array}$ & RA & 20.8 & 1090 & 28 & $(+)$ & 5 & LEF, SSZ, HCQ & 25 & 4 & 4000 \\
\hline \multicolumn{12}{|c|}{ †Age at HBV reactivation. $¥$ The dose was calculated as mean daily dose within one year before the time of reactivation. } \\
\hline $\begin{array}{l}\text { AAV } \\
\text { auto } \\
\text { infla } \\
\text { lupu }\end{array}$ & $\begin{array}{l}\text { anti-ne } \\
\text { Imune } \\
\text { mator } \\
\text { erythe }\end{array}$ & $\begin{array}{l}\text { rophil cytor } \\
\text { otic neurop } \\
\text { nyositis; LE } \\
\text { tosus; SSC }\end{array}$ & $\begin{array}{l}\text { asmic ant } \\
\text { thy; APS = } \\
=\text { leflunom } \\
=\text { systemic }\end{array}$ & $\begin{array}{l}\text { dy (ANCA } \\
\text { tiphospho } \\
\text { le; n/a = no } \\
\text { lerosis; UC }\end{array}$ & $\begin{array}{l}\text { associatec } \\
\text { pid syndro } \\
\text { available; } \\
\text { D = unclas }\end{array}$ & $\begin{array}{l}\text { Iascul } \\
\text { e; CYc } \\
\text { SS = p } \\
\text { fied cc }\end{array}$ & $\begin{array}{l}\text { is; } A D A= \\
=\text { cycloph } \\
\text { imary Sjo } \\
\text { nnective t }\end{array}$ & $\begin{array}{l}\text { dalimumab; } \mathrm{AE}=\text { autoir } \\
\text { sphamide; } \mathrm{HCQ}=\text { hydro } \\
\text { en's syndrome; RA = rh } \\
\text { sue diseases; ; }(+)=\text { po }\end{array}$ & $\begin{array}{l}\text { mune enceph } \\
\text { ychloroquine } \\
\text { Imatoid arthri } \\
\text { tive; }(-)=\text { nega }\end{array}$ & $\begin{array}{l}\text { opathy; } \\
\text { IM = idic } \\
; \text { SLE = } \\
\text { ve }\end{array}$ & $\begin{array}{l}\text { OON = } \\
\text { pathic } \\
\text { ystemic }\end{array}$ \\
\hline
\end{tabular}


Table 3

B: Clinical condition and outcome of 21 patients with HBV reactivation

\begin{tabular}{|c|c|c|c|c|c|c|c|c|c|}
\hline \multirow[t]{2}{*}{ No } & \multicolumn{5}{|c|}{ Clinical condition at HBV reactivation } & \multicolumn{4}{|c|}{ Treatment and outcome after HBV reactivation } \\
\hline & $\begin{array}{l}\text { Peak } \\
\text { ALT } \\
(U / L)\end{array}$ & $\begin{array}{l}\text { Peak T- } \\
\text { bilirubin } \\
(\mathrm{mg} / \mathrm{dL})\end{array}$ & $\begin{array}{l}\text { HBV DNA } \\
(\mathrm{IU} / \mathrm{mL})\end{array}$ & $\mathrm{HBeAg}$ & $\begin{array}{l}\lg G \\
(\mathrm{mg} / \mathrm{dL})\end{array}$ & $\begin{array}{l}\text { Antiviral } \\
\text { treatment }\end{array}$ & Clinical course & Outcome & $\begin{array}{l}\text { Follow- } \\
\text { up time } \\
\text { from } \\
\text { reversion } \\
\text { (months) }\end{array}$ \\
\hline 1 & 1400 & 0.92 & $10,500,000$ & $(+)$ & 876 & ETV & $\begin{array}{l}\text { Hepatitis resolved } 9 \text { months after } \\
\text { NUC use }\end{array}$ & Alive & 49.2 \\
\hline 2 & 127 & 1.01 & $170,000,000$ & $(+)$ & 757 & TAF & $\begin{array}{l}\text { Improved but persistent hepatitis } \\
\text { despite NUC use for a year; HBV viral } \\
\text { load decreased to } 21300 \mathrm{IU} / \mathrm{mL}\end{array}$ & Alive & 12.3 \\
\hline 3 & 1613 & 12.2 & $13,300,000$ & $(+)$ & 1100 & ETV & $\begin{array}{l}\text { Liver decompensation despite NUC } \\
\text { use, resulting in morality } 3 \text { months } \\
\text { after seroreversion }\end{array}$ & Dead & 3.4 \\
\hline 4 & 279 & 0.83 & $123,000,000$ & $(+)$ & $\mathrm{n} / \mathrm{a}$ & ETV & $\begin{array}{l}\text { Hepatitis resolved } 6 \text { months after } \\
\text { NUC use }\end{array}$ & Alive & 43 \\
\hline 5 & 147 & 0.89 & $>>170,000,000$ & $(+)$ & 862 & No & Hepatitis spontaneously resolved & Alive & 33.6 \\
\hline 6 & 255 & 0.76 & 74 & $(-)$ & 1060 & No & $\begin{array}{l}\text { Hepatitis spontaneously resolved } \\
\text { after } 2 \text { months }\end{array}$ & Alive & 9.3 \\
\hline 7 & 635 & 1.2 & $170,000,000$ & $(+)$ & 1140 & ETV & $\begin{array}{l}\text { Hepatitis resolved } 6 \text { months after } \\
\text { NUC use }\end{array}$ & Alive & 17.1 \\
\hline 8 & 748 & 0.69 & $3,590,000$ & $(-)$ & 835 & ETV & $\begin{array}{l}\text { Hepatitis resolved } 9 \text { months after } \\
\text { NUC use }\end{array}$ & Alive & 52.6 \\
\hline 9 & 371 & 3.2 & 56,000 & $(-)$ & 1190 & ETV & $\begin{array}{l}\text { Liver decompensation and hepatitis } \\
\text { improved after NUC use for } 2 \\
\text { months }\end{array}$ & Alive & 50.9 \\
\hline 10 & 104 & 1.2 & $31,300,000$ & $(+)$ & 1290 & ETV & $\begin{array}{l}\text { Hepatitis resolved } 3 \text { months after } \\
\text { NUC. Recurrent episode of hepatitis } \\
\text { after } 2 \text { months, but HBV viral load } \\
\text { already decreased significantly; the } \\
\text { hepatitis spontaneously resolved } \\
\text { again } 2 \text { months later. }\end{array}$ & Alive & 22.2 \\
\hline 11 & 175 & 0.80 & $428,00,000$ & $(+)$ & 942 & No & $\begin{array}{l}\text { Hepatitis spontaneously resolved } \\
\text { after } 3 \text { months }\end{array}$ & Alive & 13.2 \\
\hline 12 & 114 & 0.48 & $70,800,000$ & $(+)$ & 963 & ETV & $\begin{array}{l}\text { Hepatitis spontaneously resolved } \\
\text { after } 2 \text { months; Another episode of } \\
\text { hepatitis recurred after } 15 \text { months } \\
\text { with persistent elevated HBV viral } \\
\text { load, NUC was thus initiated }\end{array}$ & Alive & 26.4 \\
\hline 13 & 432 & 4.81 & 15200000 & $(+)$ & 1150 & TAF & $\begin{array}{l}\text { Hepatitis with hepatic } \\
\text { decompensation resolved after } 3 \\
\text { months }\end{array}$ & Alive & 5 \\
\hline 14 & 21 & 0.35 & $261,000,000$ & $(+)$ & 657 & No & No clinical hepatitis & Alive & 7.0 \\
\hline 15 & 20 & $\mathrm{n} / \mathrm{a}$ & $\mathrm{n} / \mathrm{a}$ & $\mathrm{n} / \mathrm{a}$ & 1510 & No & No clinical hepatitis & Alive & 4.3 \\
\hline 16 & 23 & $\mathrm{n} / \mathrm{a}$ & $\mathrm{n} / \mathrm{a}$ & $\mathrm{n} / \mathrm{a}$ & 893 & No & No clinical hepatitis & Alive & 5.9 \\
\hline 17 & 13 & $\mathrm{n} / \mathrm{a}$ & $108,000,000$ & $(+)$ & 742 & No & No clinical hepatitis & Alive & 8.4 \\
\hline 18 & 16 & $\mathrm{n} / \mathrm{a}$ & $71,000,000$ & $(+)$ & 990 & No & No clinical hepatitis & Alive & 8.0 \\
\hline 19 & 19 & 0.45 & $4,100,000$ & $(+)$ & $\mathrm{n} / \mathrm{a}$ & ETV & No clinical hepatitis & Alive & 2.2 \\
\hline 20 & 15 & $\mathrm{n} / \mathrm{a}$ & $\mathrm{n} / \mathrm{a}$ & $\mathrm{n} / \mathrm{a}$ & 597 & No & No clinical hepatitis & Alive & 4.6 \\
\hline 21 & 20 & 0.74 & $38,200,000$ & $(+)$ & 699 & ETV & No clinical hepatitis & Alive & 13.2 \\
\hline
\end{tabular}


Ten out of 13 patients with hepatitis received nucleoside analogs (NUC), either entecavir or tenofovir alafenamide. Among these patients, 8 had resolved hepatitis within 3-9 months, 1 had persistent hepatitis, and 1 died from hepatic failure. The other 3 patients with hepatitis did not receive NUC, but their hepatitis resolved spontaneously within 2-3 months after discontinuation of rituximab. In patients who developed HBsAg seroreversion without hepatitis, 6 did not receive NUC and did not develop hepatitis after a median follow-up of 9.2 months from seroreversion (range: 4.3-19.2) (Table 3B).

\section{HBV reactivation in patients with negative anti-HBc antibody}

Four patients developed hepatitis flare among 494 anti-HBc-negative individuals (patient no. 1-4 in Table 3). In addition to a negative IgM-anti-HBc and high viral loads at reactivation, all patients did not have a recent blood transfusion or unprotected sexual behaviors, which suggested that they had HBV reactivation rather than acute HBV infection. The detailed clinical courses of these patients were summarized in Fig. 3 . One patient (patient no. 3) developed hepatic failure and died 3 months after HBVr, while the hepatitis flare of the other three patients resolved with anti-viral therapy.

No predominant clinical features were observed in these four patients, except that they did not receive prior HBV vaccination. Stratified by the vaccination status based on their birth date, anti-HBc-negative patients without HBV vaccination had a higher HBV hepatitis flare rate (4/368, 1.1\%) than those with prior vaccination $(0 / 126,0 \%)$.

\section{Discussion}

In this study, 21 out of 900 HBsAg-negative patients developed HBVr after rituximab treatment for their autoimmune diseases after a median followup of 3.3 years. There were $13(1.4 \%)$ hepatitis flares and $8 \mathrm{HBsAg}$ seroreversion without hepatitis. While most of the reactivation developed in patients with positive anti-HBc antibody $(n=17)$, four reactivation events were observed in anti-HBc-negative individuals. Stratified by vaccination status (whether receiving HBV vaccination at birth), anti-HBc-negative patients without vaccination were more likely to have reactivation (4/368) than patients with vaccination $(0 / 126)$.

Current consensus and expert opinions recommended HBV status assessment before initiation of immunosuppressive therapy to stratify the patients' risk of HBVr. In cases of positive HBsAg or anti-HBc, either initiating anti-viral prophylaxis or close monitoring should be provided. ${ }^{10,18,19}$ However, our study revealed that patients in HBV endemic areas with negative anti-HBc, who should presumably be naïve to HBV infection, were also at risk of HBVr. This finding is consistent with a prospective study from Japan, which reported three RA patients with negative anti-HBc having $\mathrm{HBVr}$ after receiving immunosuppressants. ${ }^{20}$ In HBsAg-negative patients, one possible mechanism of HBVr after rituximab treatment is the presence of replication-competent HBV DNA in liver or blood, which is known as the definition of occult HBV infection (OBI). Considering the liver sample is not available in most patients and the fluctuation of serum HBV DNA level, anti-HBc is the commonly used surrogate marker for diagnosing $\mathrm{OBI}$. However, the absence of anti-HBc does not exclude OBI in HBV endemic area. ${ }^{21}$ This is supported by epidemiologic studies in Taiwan and Iran, where the $\mathrm{OBI}$ is observed in $4.8-16 \%$ patients with negative anti-HBc. ${ }^{22,23}$ Recent studies also reported that $1-20 \%$ OBI patients are "seronegative" (negative anti-HBc and negative anti-HBs), which is possibly caused by a progressive loss of HBc and HBs antibodies over time. ${ }^{21,24,25}$ In addition, a study in Taiwan showed that universal HBV vaccination at birth decreased OBI prevalence; in anti-HBc-negative patients without vaccination, the $\mathrm{OBI}$ prevalence is as high as $4.8 \%$, in contrast to $0 \%$ with HBV vaccination. ${ }^{22}$ Our data also showed that, the "unvaccinated group" had higher HBVr rate $(4 / 368,1.1 \%)$ compared to that in the vaccinated group $(0 / 126)$. Therefore, we believe that a certain amount of anti$\mathrm{HBc}$-negative patients, especially those without prior vaccination in HBV-endemic area, may have OBI, like the four anti-HBc-negative patients with $\mathrm{HBV}$ in our study. While the definite diagnosis of $\mathrm{OBI}$ is sometimes challenging at HBV-endemic area, the risk of HBVr in patients with seronegative $\mathrm{OBI}$ should not be overlooked. Regular follow-up of HBV serology should be considered in these patients, when they are going to receive high-risk agents such as rituximab.

Previous studies regrading rituximab-associated HBVr primarily focused on patients with hematologic malignancies and RA, and the data of other autoimmune diseases are scarce. ${ }^{2,11-13}$ It was reported that systemic autoimmune diseases, such as systemic lupus erythematosus (SLE), had higher rates of opportunistic infections than RA. ${ }^{26}$ A retrospective study also revealed 3/157 (1.9\%) anti-HBc-positive patients with SLE experiencing HBsAg seroreversion after receiving immunosuppressants. ${ }^{27}$ Our study show that the HBVr rate is numerically higher in patients with some autoimmune diseases (including SLE, Sjogren's syndrome, antiphospholipid syndrome and vasculitis) compared to RA, but the difference was statistically insignificant (Fig. 2B and Supplement Table 1).

We found the absence of serum anti-HBs antibody at rituximab initiation associated with HBVr, consistent with the previous reports. ${ }^{12,13}$ While hypogammaglobulinemia was reported as a predictor for severe infection in rheumatic patients receiving rituximab, we did not find significant correlations between the baseline IgG and the HBVr. ${ }^{28}$ Taking the above findings, it is postulated that the vitality of anti-HBs-secreting plasma cell clones and the serum level of anti-HBV immunoglobulin, as reflected by anti-HBs, might serve as a better indicator of anti-HBV immunity than the overall status of humoral immunity (judging by baseline lgG). Rituximab induces peripheral B cell depletion, which leads to the loss of anti-HBs, might explain the higher HBVr rates in individuals receiving rituximab. However, further translational studies are required to explore this concept. 
Although the concurrent steroid use with other biologics increase the risk of HBVr in RA patients with chronic HBV, the impact of steroid in HBsAgnegative patients remains controversial. ${ }^{29,30}$ In our study, all patients with HBVr received mean daily steroid dose less than $10 \mathrm{mg}$, and the concomitant steroid use with rituximab is not associated with HBVr in Cox regression analysis. Nonetheless, given the variable course of steroid treatment during long follow-up period, the effect of steroid and duration were difficult to clarify.

There are a few limitations in this study. First, there were some missing data regarding the HBV serology, due to the retrospective study design and the lack of universal monitoring strategy for HBV during study period (from 2006 to 2019). The incidence of HBVr without hepatitis might be underestimated, especially for anti-HBc-negative patients, whose HBV serology was rarely regularly checked. Nonetheless, because the liver function tests were monitored at a 1 to 3-month interval for every patient, events of HBV-associated hepatitis were not likely to be missed. Secondly, the HBV viral load at rituximab initiation was not available for most of the patients. Although single HBV DNA measurement is not sufficient to exclude OBI in HBV endemic areas, combining HBV viral load and prior HBV vaccination status may stratify patients' risk better for anti-HBc-negative individuals. Further studies are required to explore this hypothesis. Finally, the number of patients with some rheumatic diagnoses were limited, making detailed analysis and comparison in these patients difficult.

In conclusion, anti-HBc-negative patients, especially those without vaccination at birth, were still at risk of HBV reactivation after receiving rituximab for their autoimmune diseases. Risk stratification based on HBsAg and anti-HBc at rituximab initiation is insufficient to identify all patients at risk in HBV endemic areas, where occult HBV is prevalent. Therefore, HBV serology follow-up should be considered for all HBsAg-negative patients receiving rituximab for autoimmune diseases.

\section{Declarations}

\section{Acknowledgements:}

We would like to thank the staff of the Department of Medical Research, National Taiwan University Hospital for the Integrated Medical Database.

\section{Data Availability:}

The authors confirm that the data supporting the findings of this study are available within the article and its supplementary materials.

\section{Ethical Approval:}

The study was approved by the Ethics Committee of National Taiwan University Hospital (reference number 202010014RINB) in harmony with the Declaration of Helsinki.

\section{Animal Research (Ethics):}

Not applicable.

\section{Consent to Participate (Ethics):}

Written informed consent for participation was not required. Study participant was enrolled through retrospective analysis, which was approved by the Ethics Committee of National Taiwan University Hospital.

\section{Consent to Publish (Ethics):}

All authors revisited the manuscripts critically for important intellectual content, and all authors approved the final version to be published.

\section{Clinical Trials Registration:}

Not applicable

\section{Author Contribution:}

TYL (Ting-Yuan Lan) planned the study, acquired data, analysed data, interpreted data and drafted the manuscript. YCL planned the study, acquired data, analysed data, interpreted data and critically reviewed the manuscript. TCT and HCY analysed data, interpreted data and critically reviewed the manuscript. JHK, CFC, TJL, SCH, SCHL and KJL acquired data and critically reviewed the manuscript. SCH (Song-Chou Hsieh) planned the study, acquired data, analysed data, interpreted data and critically reviewed the manuscript.

\section{Conflict of Interest:}

There are none to declare for all authors.

\section{Funding:}


All authors did not receive any fees or funding for this publication.

\section{References}

1. Yuen MF, Chen DS, Dusheiko GM, et al. Hepatitis B virus infection. Nat Rev Dis Primers.2018;4:18035.

2. Perrillo RP, Gish R, Falck-Ytter YT. American Gastroenterological Association Institute technical review on prevention and treatment of hepatitis B virus reactivation during immunosuppressive drug therapy. Gastroenterology.2015;148(1):221-244 e223.

3. Fanouriakis A, Kostopoulou M, Alunno A, et al. 2019 update of the EULAR recommendations for the management of systemic lupus erythematosus. Ann Rheum Dis.2019;78(6):736-745.

4. Ramos-Casals M, Brito-Zeron P, Bombardieri S, et al. EULAR recommendations for the management of Sjogren's syndrome with topical and systemic therapies. Ann Rheum Dis.2020;79(1):3-18.

5. Fasano S, Gordon P, Hajji R, Loyo E, Isenberg DA. Rituximab in the treatment of inflammatory myopathies: a review. Rheumatology (Oxford).2017;56(1):26-36.

6. Rodriguez-Pinto I, Cervera R, Espinosa G. Rituximab and its therapeutic potential in catastrophic antiphospolipid syndrome. Ther Adv Musculoskelet Dis.2015;7(1):26-30.

7. Tieu J, Smith R, Basu N, et al. Rituximab for maintenance of remission in ANCA-associated vasculitis: expert consensus guidelines. Rheumatology (Oxford).2020;59(4):e24-e32.

8. Smolen JS, Landewe RBM, Bijlsma JWJ, et al. EULAR recommendations for the management of rheumatoid arthritis with synthetic and biological disease-modifying antirheumatic drugs: 2019 update. Ann Rheum Dis.2020;79(6):685-699.

9. Di Bisceglie AM, Lok AS, Martin P, Terrault N, Perrillo RP, Hoofnagle JH. Recent US Food and Drug Administration warnings on hepatitis B reactivation with immune-suppressing and anticancer drugs: just the tip of the iceberg? Hepatology.2015;61(2):703-711.

10. Terrault NA, Lok ASF, McMahon BJ, et al. Update on prevention, diagnosis, and treatment of chronic hepatitis B: AASLD 2018 hepatitis B guidance. Hepatology.2018;67(4):1560-1599.

11. Kuo MH, Tseng CW, Lee CH, Tung CH, Tseng KC, Lai NS. Moderate Risk of Hepatitis B Virus Reactivation in HBsAg(-)/HBcAb(+) Carriers Receiving Rituximab for Rheumatoid Arthritis. Sci Rep.2020;10(1):2456.

12. Chen $Y M$, Chen $H H$, Huang WN, et al. Reactivation of hepatitis B virus infection following rituximab treatment in HBsAg-negative, HBcAb-positive rheumatoid arthritis patients: A long-term, real-world observation. Int J Rheum Dis.2019;22(6):1145-1151.

13. Tien YC, Yen HH, Li CF, et al. Changes in hepatitis B virus surface antibody titer and risk of hepatitis B reactivation in HBsAg-negative/HBcAbpositive patients undergoing biologic therapy for rheumatic diseases: a prospective cohort study. Arthritis Res Ther.2018;20(1):246.

14. Varisco V, Vigano M, Batticciotto A, et al. Low Risk of Hepatitis B Virus Reactivation in HBsAg-negative/Anti-HBc-positive Carriers Receiving Rituximab for Rheumatoid Arthritis: A Retrospective Multicenter Italian Study. J Rheumatol.2016;43(5):869-874.

15. van Vollenhoven RF, Fleischmann RM, Furst DE, Lacey S, Lehane PB. Longterm Safety of Rituximab: Final Report of the Rheumatoid Arthritis Global Clinical Trial Program over 11 Years. J Rheumatol.2015;42(10):1761-1766.

16. Barone M, Notarnicola A, Lopalco G, et al. Safety of long-term biologic therapy in rheumatologic patients with a previously resolved hepatitis B viral infection. Hepatology.2015;62(1):40-46.

17. Ni YH, Chang MH, Wu JF, Hsu HY, Chen HL, Chen DS. Minimization of hepatitis B infection by a 25-year universal vaccination program. $J$ Hepatol.2012;57(4):730-735.

18. Loomba R, Liang TJ. Hepatitis B Reactivation Associated With Immune Suppressive and Biological Modifier Therapies: Current Concepts, Management Strategies, and Future Directions. Gastroenterology.2017;152(6):1297-1309.

19. Koutsianas C, Thomas K, Vassilopoulos D. Reactivation of hepatitis B virus infection in rheumatic diseases: risk and management considerations. Ther Adv Musculoskelet Dis.2020;12:1759720X20912646.

20. Fukuda W, Hanyu T, Katayama M, et al. Incidence of hepatitis B virus reactivation in patients with resolved infection on immunosuppressive therapy for rheumatic disease: a multicentre, prospective, observational study in Japan. Ann Rheum Dis.2017;76(6):1051-1056. 
21. Raimondo G, Locarnini S, Pollicino T, et al. Update of the statements on biology and clinical impact of occult hepatitis B virus infection. $J$ Hepatol.2019;71(2):397-408.

22. Hsu HY, Chang MH, Ni YH, Chiang CL, Wu JF, Chen HL. Universal infant immunization and occult hepatitis B virus infection in children and adolescents: a population-based study. Hepatology.2015;61(4):1183-1191.

23. Ghaziasadi A, Fakhari Z, Aghcheli B, et al. High prevalence of occult hepatitis B infection (OBI) among healthy children and their parents in Alborz province, Iran; Vertical OBI, myth or truth? Liver Int.2020;40(1):92-100.

24. Hsu HY, Chang MH, Ni YH, et al. Chronologic changes in serum hepatitis B virus DNA, genotypes, surface antigen mutants and reverse transcriptase mutants during 25-year nationwide immunization in Taiwan. J Viral Hepat.2017;24(8):645-653.

25. Torbenson M, Thomas DL. Occult hepatitis B. Lancet Infect Dis.2002;2(8):479-486.

26. Hsu CY, Ko CH, Wang JL, Hsu TC, Lin CY. Comparing the burdens of opportunistic infections among patients with systemic rheumatic diseases: a nationally representative cohort study. Arthritis Res Ther.2019;21(1):211.

27. Chen $\mathrm{HC}$, Chung $\mathrm{CH}$, Wang $\mathrm{CH}$, et al. Increased risk of sudden sensorineural hearing loss in patients with hepatitis virus infection. PLoS One.2017;12(4):e0175266.

28. Md Yusof MY, Vital EM, McElvenny DM, et al. Predicting Severe Infection and Effects of Hypogammaglobulinemia During Therapy With Rituximab in Rheumatic and Musculoskeletal Diseases. Arthritis Rheumatol.2019;71(11):1812-1823.

29. Chen MH, Chen MH, Liu CY, et al. Hepatitis B Virus Reactivation in Rheumatoid Arthritis Patients Undergoing Biologics Treatment. J Infect Dis.2017;215(4):566-573.

30. Wong GL, Wong VW, Yuen BW, et al. Risk of hepatitis B surface antigen seroreversion after corticosteroid treatment in patients with previous hepatitis B virus exposure. J Hepatol.2020;72(1):57-66.

\section{Figures}

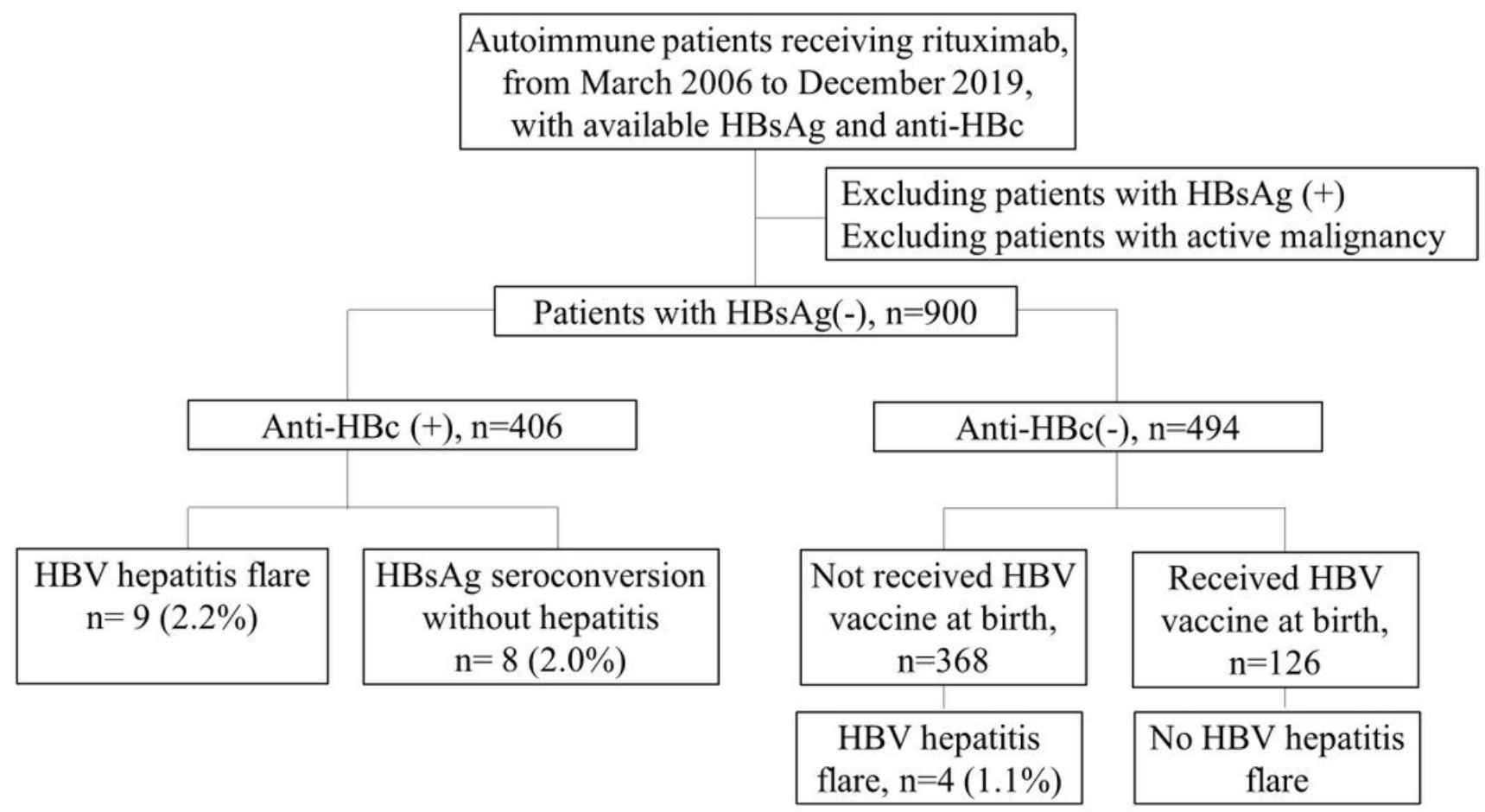

\section{Figure 1}

Patients with negative HBsAg receiving at least one cycle of rituximab for various rheumatic diseases were enrolled. In addition to anti-HBc-positive patients, four out of $368(1.1 \%)$ anti-HBc-negative patients who did not have HBV vaccination at birth had HBV hepatitis flare. 
(A)
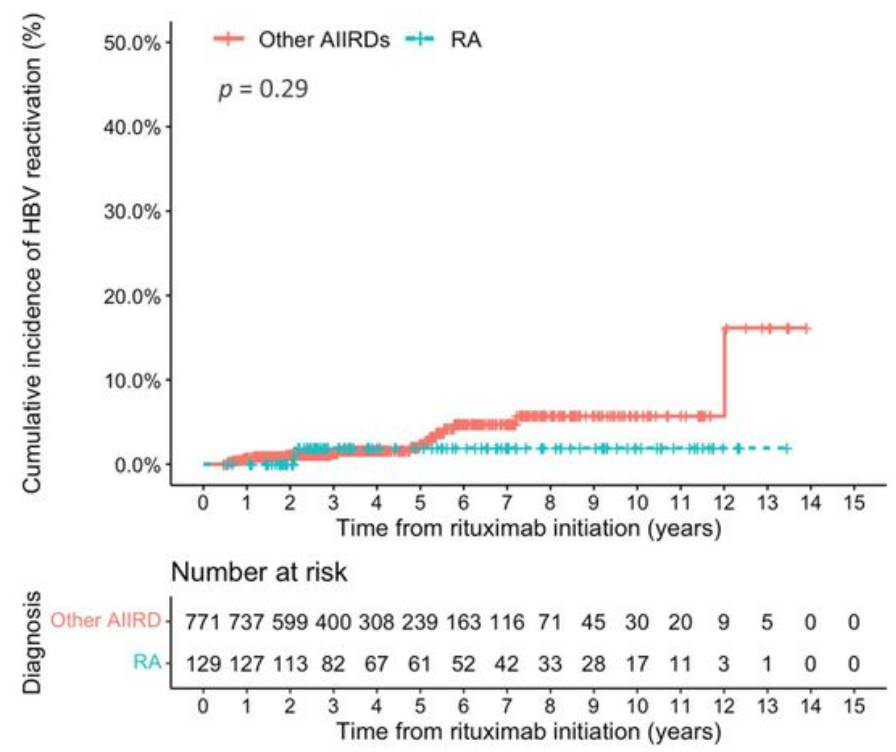

(B)
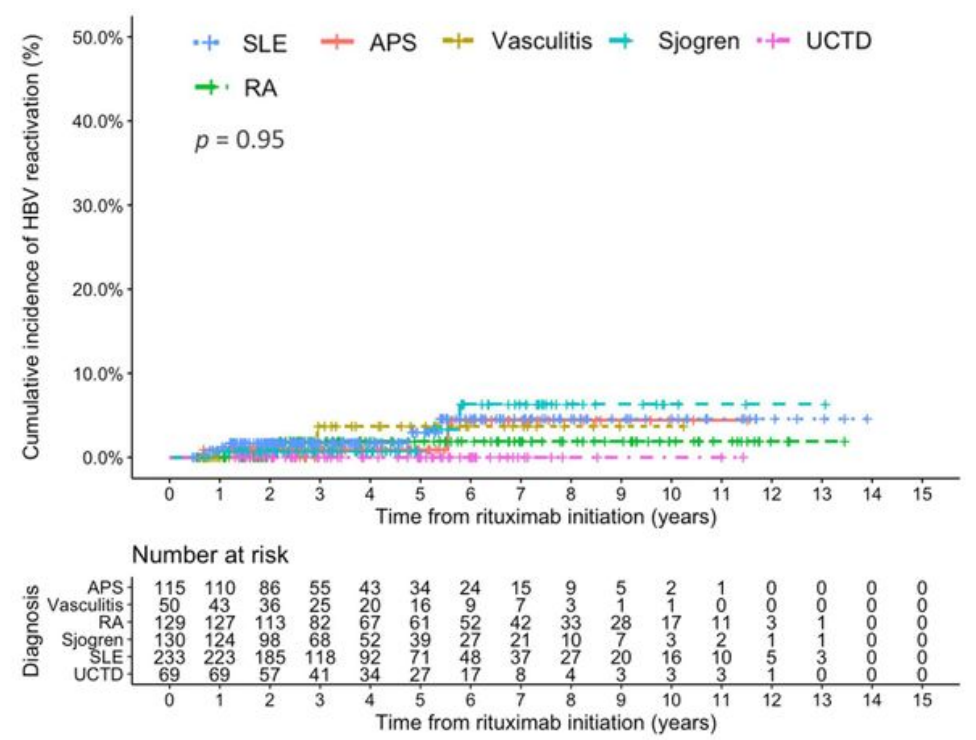

Figure 2

Cumulative incidence of HBV reactivation stratified according to different autoimmune diseases. (A) Comparison between rheumatoid arthritis (RA) and other autoimmune inflammatory rheumatic disease (AIIRD). (B) Comparison between six AllRDs ( $>50$ for each individual diagnoses), including RA, antiphospholipid syndrome (APS), systemic lupus erythematosus (SLE), Sjogren syndrome and unclassified connective tissue disease (UCTD).

(A)

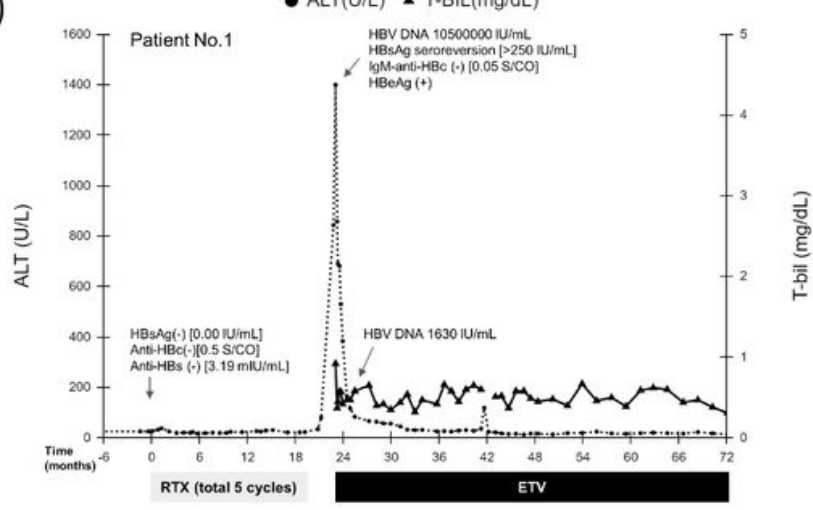

(C)

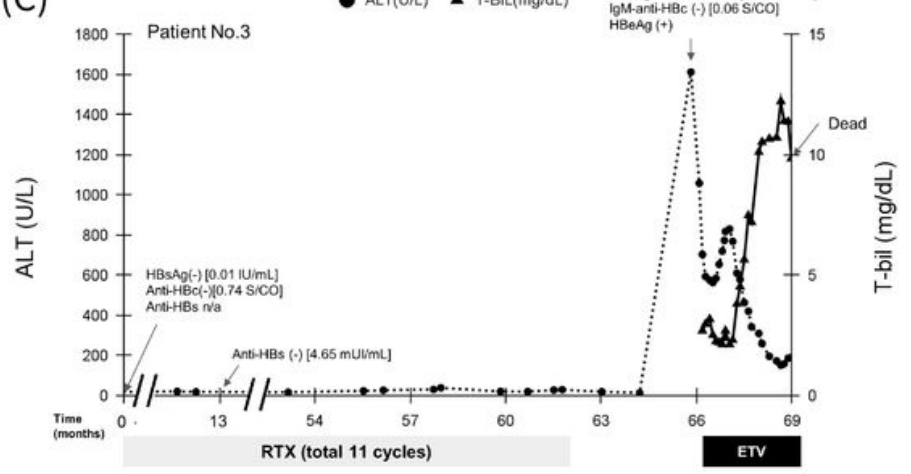

(B)

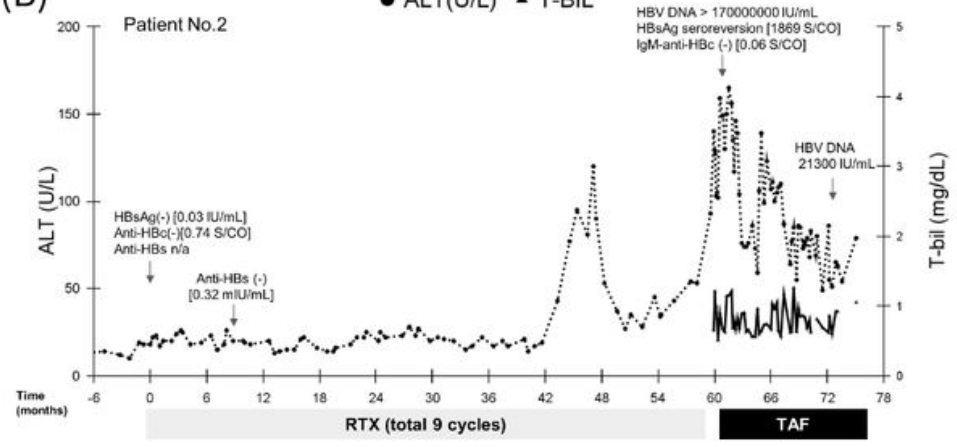

(D)

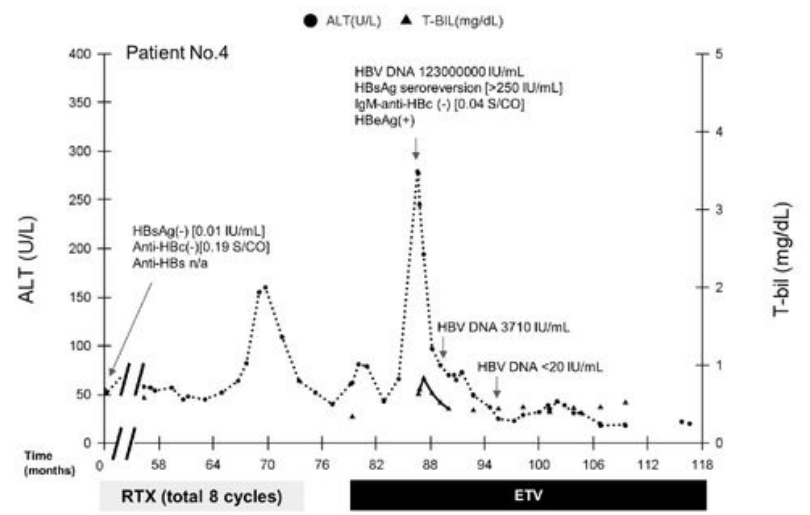

Figure 3

The clinical course of four anti-HBc-negative patients experiencing HBV hepatitis flare (patient no. 1-4 in table 1). (A) A 57-year-old woman diagnosed with autoimmune optic neuropathy had HBV-associated hepatitis flare after 5 cycles of rituximab. (B) A 46-year-old woman with inflammatory myositis; prior to HBV reactivation, there was an episode of ALT elevation with spontaneous resolution attributed to her myositis disease flare at that time. (C) A 69-year-old woman with Sjogren syndrome and interstitial lung disease had hepatitis flare and died from hepatic 
decompensation. (D) A 59-year-old woman with inflammatory myositis also had an episode of ALT elevation attributed to her myositis diseases flare prior to HBV reactivation. ETV = entecavir; TAF = tenofovir alafenamide; RTX = rituximab.

\section{Supplementary Files}

This is a list of supplementary files associated with this preprint. Click to download.

- Supplementarytable.docx 